\title{
Pesantrenisasi Sebagai Pembentukan Spiritualitas Mahasiswa (Studi Kasus Wajib Lulus BTA-PPI di IAIN Purwokerto)
}

\author{
Arif Hidayat \\ Institut Agama Islam Negeri (IAIN) Purwokerto \\ E-mail: arif19hidayat88@gmail.com \\ Received: January 20, 2020 | Accepted: June 1, 2020
}

\begin{abstract}
The writing attempts to examine about 'a must to be graduated' phenomena of al-Qur'an Reading and Writing (BTA) dan The Knowledge of Religious Service Implementation (PPI) at The State Islamic Institute of Purwokerto. This idea may be interesting to review since the materialistic living in global culture has brought anxiety concerning a moral ethics alteration of youth that becomes uncontrolled. From this side, therefore, pesantren (Islamic boarding school) becomes the solution to form spirituality value through BTA-PPI Graduated Compulsory, which is programmed educationally by IAIN Purwokerto. Students, who failed BTA-PPI, must "mondok" (be quarantined in a boarding house) until they are really mastered the materials which can be carried out well in daily life. As a result, this kind of establishment, which is held by BTA-PPI leads the students of IAIN Purwokerto to implement successfully by knowing tartil and tajwid properly, understanding imla pattern, and the importance of Qur'an short verses (juz 30). Related to the knowledge of practicing worship, it may be measured on the fundamental piety/faith, Islam, and ihsan (elements, requirements, and pillars included) that could be implemented to the life of social and nationality
\end{abstract}

\begin{abstract}
Abstrak
Tulisan ini berusaha untuk mengkaji fenomena 'wajib untuk lulus' Baca Tulis al-Qur'an (BTA) dan Pengetahuan Pengamalan Ibadah (PPI) di Instiut Agama Islam Negeri Purwokerto. Gagasan ini menarik untuk dikaji karena kehidupan yang matrialistis dalam budaya global telah menimbulkan kahawatiran dapat merubah etika moral anak muda menjadi sulit terkendali. Pada sisi inilah, pesantren menjadi solusi untuk membentuk nilai-nilai spiritualitas melalui program wajib lulus BTA-PPI yang dirancang oleh IAIN Purwokerto dalam sistem pendidikan. Mahasiswa yang tidak lulus BTA-PPI diwajibkan untuk
\end{abstract}


"mondok" sampai benar-benar menguasai materi dan dapat dipraktikan dengan baik dalam kehidupan sehari-hari. Hasilnya, pembinaan BTA-PPI bagi mahasiswa IAIN Purwokerto terlaksana dengan baik, yakni dengan mahasiswa mengetahui tartil dan tajwid yang benar, mengetahui pola imla dan materi pentingnya hafalan surat pendek (juz 30). Adapun terkait dengan pengetahuan pengamalan ibadah, hal itu dapat diukur dengan peningkatan kemampuan dasar iman, Islam, dan ikhsan (beserta unsur, syarat, dan rukun) yang diimplementasikan dalam kehidupan bermasyarakat, berbangsa, dan bernegara.

\section{Keywords}

Pesantren, al-Qur'an, students, spirituality.

\section{Pendahuluan}

Salah satu kekhawatiran manusia yang paling puncak di abad mutakhir ini adalah hancurnya rasa kemanusiaan dan hilangnya semangat religius dalam segala aktivitas kehidupanya. Keadaan seperti itu dapat ditandai dengan hadirnya penemuan-penemuan baru di berbagai bidang teknologi modern yang telah banyak mengubah pola pikir masyarakat dari religius menjadi matrialistis, individual, dan memudarnya nilai-nilai spiritual. Dalam belakangan ini, kehidupan makin terpengaruh oleh budaya global membuat banyak orang kehilangan kompetensi dasar membaca al-Qur'an dan pengetahuan pengamalam ibadah. Padahal, kompetensi ini menjadi salah satu pembentuk karakter orang Islam dengan nilai moral dan jiwa spiritual yang bertumpu pada akhlakul karimah. Dalam situasi seperti inilah, transformasi nilai-nilai etika ilahiyah melalui lembaga pendidikan memegang peranan yang signifikan untuk ikut meluruskan penyimpangan-penyimpangan akibat ekses negatif ruang global.

Dengan melihat fenomena belakangan ini, maka makin mirislah dengan berbagai persoalan pelik terkait mulai berkurang perhatian masyarakat Islam pada al-Qur'an. Kemajuan teknologi dan kecanggihan material yang dianggap sebagai puncak kejayaan peradaban justru menimbulkan orang melupakan alQur'an sebagai kitab pegangan Umat Islam. Hal ini makin membuat umat Islam cemas, khawatir, dan bingung untuk segera mengatasi makin berkurangnya orang yang hafal al-Qur'an. Umat Islam dituntut untuk bijak karena sesungguhnya "al-Qur'an adalah Islam itu sendiri" dan sesegera mungkin menemukan solusi untuk menumbuhkan semangat menghafal alQur'an.

Tidak semua orang peduli dengan hilangnya penghafal al-Qur'an yang 
ada di sekitarnya. Gagasan bahwa manusia sebagai khalifah di alam semesta belakangan ini mulai diabaikan dari nilai-nilai yang ada di dalam al-Qur'an. Padahal, al-Qur'an memiliki nilai-nilai yang sangat berguna dalam kehidupan manusia (Sachiko Murata dan William C. Chittick, 2005: 16). Naturalitas pandangan dunia al-Qur'an merepresentasikan suatu pendidikan bahwa umat Islam medasarkan acuan yang senantiasa kontekstual terhadap perkembangan zaman. Apabila ingin menyikapi permasalahan tersebut, maka umat Islam harus meyakini bahwa hidup harmoni dengan lingkungan adalah berpegang kepada al-Qur'an dan Hadis sebagaimana yang dianjurkan oleh Nabi Muhammad (Muchtar, 2012: 26). Pandangan ibadah tidak hanya mengacu pada ritual untuk berdialog langsung dengan Tuhan, melainkan juga dapat dilakukan dengan turut berpartisipasi menjadi bagian dari orang yang mengerti apa itu Islam, yakni dengan cara hafal al-Qur'an. Orang-orang yang memahami hakikat semacam ini lebih banyak ditemukan di pondok pesantren yang memiliki kedalaman nilai dan rasa untuk mengenali dirinya sendiri dan mentransformasikan dalam hidup. Dalam dialektika lingkungan yang harmonis memang sudah seharusnya manusia memahami bahwa keindahan inderawi pun dapat menuju pada hakikat keindahan tunggal dari Allah melalui al-Qur'an.

IAIN Purwokerto sebagai institusi pendidikan berlabel Islam, mempunyai tanggung jawab akademis terhadap setiap mahasiswa agar dapat memiliki kemampuan dasar bidang agama Islam sehingga dapat menjalani proses pendidikan dengan baik. Tujuannya agar mahasiswa mampu menjadi seorang intelektual dengan wawasan keagamaan yang baik sekaligus mampu mentransformasikan ilmu yang dimilikinya ke mahasiswa. Mahasiswa sebagai intelektual dituntut memiliki kualifikasi dan kompetensi yang diperlukan sesuai dengan tugas dan bidang keilmuannya. Oleh karena itulah, IAIN Purwokerto juga harus bisa meningkatkan dan mengembangkan kompetensi mahasiswa sehingga dapat mengarahkan pada pembentukan moral maupun spiritual sebagai karakter Islami.

Untuk bisa membentuk dinamika yang religius, maka mahasiswa harus menguasai kompetensi dasar baca tulis al-Qur'an dan pengetahuan pengamalam ibadah secara mendalam. Untuk memenuhi tuntutan akademis tersebut, maka IAIN Purwokerto menyelenggarakan pembinaan BTA-PPI bagi mahasiswa IAIN Purwokerto di tahun 2016 ini. Pembinaan BTA-PPI bagi mahasiswa IAIN Purwokerto merupakan standarisasi untuk mengukur tingkat kemampuan minimal mahasiswa di bidang baca, tulis, dan hafalan al-Qur'an serta praktek pengalaman ibadah untuk bisa lulus. 


\section{Kerangka Teori}

Penelitian ini menggunakan teori memori diperkenalkan oleh Sigmund Freud (2006: 15) dalam buku Psikoanalisis. Ia membagi struktur kepribadian dalam tiga hal, yakni id, ego dan superego. Dalam struktur tersebut terbentuk asal-usul sebuah pengetahuan itu melekat dalam diri seseorang. Kemampuan berpikir dan daya nalar seseorang tidak terbentuk begitu saja, melainkan karena adanya dorongan ingatan yang tersembunyi seperti gunung es yang terandam di dalam permukaan air. Suatu waktu, hal itu bisa muncul kembali sebagai bagian dari diri orang tersebut (Bartensz, 2006: 53).

Memori (atau yang lebih dikenal sebagai 'ingatan' dalam struktur fisik manusia) dapat membentuk kognisi yang melibatkan otak untuk data-data tertentu atas tempo waktu tertentu. Boleh dikatakan, memori adalah daya rekam di dalam otak yang dimiliki oleh seseorang melalui sistem saraf yang bekerja untuk menghubungkan keadaan dengan masa lampau dan memunculkan kembali pada saat dibutuhkan. Daya rekam seseorang ada yang mudah untuk dimunculkan kembali dan ada yang sulit untuk dimunculkan kembali. Kadang, ada peristiwa yang tidak ingin tersimpan di dalam otak justru tetap tersimpan sampai sekarang. Dalam praktiknya, ada beberapa hal yang dilakukan oleh otak untuk menyimpan data, yakni dari memasukkan informasi (econding), menyimpan (storage), dan memunculkan kembali (retrieval stage).

Daya memori seseorang terbentuk dalam aktivitas keseharian melalui proses pembelajaran. Belajar sebagai transformasi ilmu pengetahuan tidak akan berjalan dengan baik apabila tidak ada penghayatan dan pendalaman materi sebagai bagian dari kehidupan. Daya memori seseorang dapat digunakan untuk merekam keterkesanan melalui proses pembelajaran sehingga ketika kelak mengalami masalah, maka ia dapat mengatasinya berdasarkan hal-hal yang pernah ia pelajari.

Sementara itu, aktivitas belajar dipahami sebagai proses perubahan di dalam kepribadian manusia, dan perubahan tersebut ditampakkan dalam bentuk peningkatan kualitas dan kuantitas tingkah laku seperti peningkatan kecakapan, pengetahuan, sikap, kebiasaan, pemahaman, keterampilan, daya pikir, dan lain-lain kemampuan (Freire, 2007: 94). Dari pengertian di atas dapat dibuat kesimpulan bahwa agar terjadi proses belajar atau terjadinya perubahan tingkah laku perlu kesiapan menerima pengalaman belajar dari peserta didik dan pengalaman belajar tersebut harus sesuai dengan tujuan yang ingin dicapai. Proses belajar itu terjadi secara internal dan bersifat pribadi dalam diri peserta didik agar proses belajar tersebut mengarah pada tercapainya tujuan, maka pendidik harus merencanakan dengan saksama dan sistematis 
berbagai pengalaman belajar yang memungkinkan perubahan tingkah laku sesuai dengan apa yang diharapkan (Ahmadi dan Supriyono, 2004: 16).

Sebuah peristiwa akan masuk sebagai informasi manakala dilihat, didengar, dan/atau dirasakan, yang kemudian dipraktikan dalam kehidupannya. Tiga hal itu menjadi komponen penting bagi sebuah data dapat disimpan dalam memori manusia dengan ditambah pengamalan dalam kehidupan sehari-hari. Kerja dari pancaindra dalam menerima setiap stimulus dari luar akan secara otomatis merekam yang akan mendapat penghayatan dengan diamalkan. Ada sebuah istilah bahwa "ilmu tidak akan berguna tanpa amal.” Hal itu menjelaskan bahwa kita tidak hanya belajar saja, tetapi juga mengamalkan ilmu sehingga bisa berkembang.

Dalam proses perekaman data atau informasi, ada yang berjalan dengan baik dan ada yang tidak berjalan. Peristiwa yang terlintas sepintas biasanya tidak akan terekam dengan baik, namun bisa saja muncul sebagai elemen bawah sadar yang entah pada waktu tertentu dapat muncul, walaupun orang tersebut telah melupakannya. Peristiwa yang abadi dalam memori adalah manakala penglihatan, pendengaran, dan turut merasakan bersatu sebagai sebuah pengalaman (yang juga ditunjang oleh seluruh sensor) sebagai keberkesanan. Hal inilah yang memungkinkan terjadi perekaman oleh otak secara utuh sebagai peristiwa karena adanya keterlibatan penuh.

Dalam proses belajar, memori menjadi sangat penting untuk mengingat materi yang diberikan oleh guru. Makanala ia hanya mendengarkan saja, potensi untuk lupa sangat tinggi. Seseorang yang mendengarkan dan melihat memiliki kemungkinan untuk menyerap informasi, walaupun tidak dalam bentuk yang utuh. Informasi akan menjadi sangat berkembang, manakala dalam proses belajar, seseorang berusaha untuk melihat, mendengar, dan mengamalkan dalam kehidupan. Setidaknya, peserta didik berusaha untuk mengimajinasikan informasi yang diperoleh ke dalam kehidupannya.

Konsep dalam penelitian ini mengacu pada Toksonomi Bloom. Konsep ini menekankan pada kemampuan seperti afektif, kognitif, dan psikomotorik harus senantiasa selaras untuk menciptakan kreasi-kreasi di dalam diri (Ahmadi dan Supriyono, 2004: 24). Kemampuan afektif mengontrol wilayah perasaan untuk selalu menjadikan diri terlecut dan bangkit untuk meriah sesuatu yang hendak diimpikan. Kemampuan kognitif mengarahkan untuk senantias bersikap untuk percaya sesuai dengan prinsip hidup untuk maju dan berkembang. Adapun kemampuan psikomotorik akan mendorong diri secara psikis untk selalu memandang diri memiliki potensi yang dapat dikembangkan. Ketiga kemampuan itu membentuk relasi sebagai konsepsi dalam diri seseorang, yang pada akhirnya dapat menjadi "proses yang berproses" untuk mandiri. Proses untuk mandiri adalah pola perkembangan seseorang yang akan 
tampak pada saat membentuk jiwa menjadi mandiri. Selama manusia itu dalam hidup, sesungguhnya dia sedang menyatakan diri sedang berproses untuk terus menjadi mandiri. Oleh karena itu, kemandirian dapat disebut sebagai wilayah proses yang berproses untuk menemukan jiwa mandiri sesuai dengan disiplin yang ditempuh.

Umat Islam memiliki berkepentingan memberikan kontribusi optimal bagi terwujudnya generasi muda yang memahami esensi Islam dengan berdasarkan pada al-Qur'an. Pemahaman yang baik mengenai al-Qur'an akan menjadi sebuah bangunan sosial yang memungkinkan setiap individu dan kelompok mengembangkan dirinya melalui cara-cara yang beradab (Azarpour, dkk, 2004). Dari paradigma tersebut, dapat dipahami bahwa dalam beragama Islam (mau menghayati dan mengimplementasikan ajaran agama), berilmu (tahu dan bisa memanfaatkan ilmu pengetahuan yang dimiliki), sadar budaya (toleran terhadap keberagaman yang ada di masyarakat sehingga tercipta keharmonian) senantiasa didasarkan pada al-Qur'an sebagai pegangan. Dalam hal ini, menghafal al-Qur'an merupakan tanggung jawab sebagai kebutuhan umat Islam sepanjang zaman. Ada kewajiban bagi umat Islam untuk belajar menghafal al-Qur'an sebagai sebuah konsekuensi penting dalam kehidupan sehari-hari.

Konsep keberhidupan yang tertuang di dalam al-Qur'an juga dipahami sebagai sistem dan skenario untuk mencapai tujuan dengan pembelakan pada umat Islam terkait juga dengan cara menjalani kehidupan sehari-hari agar selamat dunia akhirat. Dalam hal ini, rambu-rambu evaluasi sudah tertera dengan jelas di dalam al-Qur'an (Che Noh, 2013: 1340-1344). Metode yang digunakan dalam menghafal al-Qur'an adalah dengan cara One Day One Ayat dengan ustad membacakan lagu tartil. Proses yang dilakukan dalam pelaksanaan menghafal ini membutuhkan waktu yang cukup lama, kadang juga masih lupa lagi sehingga kadang juga harus mengulang. Metode menghafal al-Qur'an yang seperti ini dirasa masih kurang efisien karena dapat menjadikan orang jenuh.

Kebanyakan orang, dalam menghafal al-Qur'an hanya berusaha menghafal, tetapi tidak berusaha untuk memahami nilai dan kandungan yang berada di dalamnya. Melalui pembelajaran duroh, seseorang tidak hanya menghafal, tetapi juga mendapatkan ulasan yang menarik mengenai kajian dan tafsir sesuai dengan tema-tema yang aktual pada masa sekarang ini. Hal ini pun juga dilakukan dengan interaksi singkat untuk pendalaman penguasaan dan usaha untuk membentuk respons bagi penyimak. Penerapan dari metode menghafal ini dilakukan dengan empat langkah, yaitu permainan, cerita, isyarat tangan, dan pendinginan. Dengan langkah tersebut, seseorang diarahkan untuk menghafal dan memahami. Pembelajaran ini juga diulang 
hingga tiga kali yang memungkinkan orang lulus semua. Adapun hal yang sebenarnya menjadi catatan penting dalam belajar adalah metode dan strategi yang dilakukan sehingga berhasil menjadikan orang bisa membaca al-Qur'an dengan cepat.

\section{Metode}

Penelitian ini dilakukan di IAIN Purwokerto terkait dengan Program BTA/PPI yang wajib lulus dan apabila tidak lulus, mahasiswa diwajibkan untuk mondok di pesantren selama setahuan atau lebih (sampai mahasiswa tersebut lulus). Pesantren di sekitar IAIN Purwokerto memiliki sistem pembelajaran dan kurukulum dasar yang sesuai dengan modul BTA/PPI. Oleh karena itu, subjek penelitianya adalah pengasuh, ustadz pendamping, pendiri, dan di Ma'had IAIN Purwokerto. Dengan demikian, penelitian ini menggunakan etnometodologi, yang mana metode ini digunakan sebagai metode untuk menggambarkan bagaimana perilaku sosial subjek dalam merespons masalah (cultural behaviour), apa yang diyakini dan diketahui (termasuk di dalamnya ideology) (cultural knowlegde), dan hal-hal apa yang dibuat dan digunakan (cultural artifact) oleh subjek penelitian sebagaimana adanya dalam kaca mata subjek penelitian itu sendiri. Dengan kata lain, penelitian ini berupaya memahami bagaimana subjek memandang, menjelaskan, dan menggambarkan tata hidup mereka sendiri (Muhadjir, 1996: 94). Dimensi konseptual metodologis yang dipakai dalam penelitian ini yang bercorak ethnografi ini lebih cenderung menggunakan induksi-generatifkonstruktif. Artinya, penelitian ini mengarah pada penemuan konstruksi (yang berkaitan dengan pemahaman konsep-konsep terutama berkaitan dengan tradisi kematian) dan penemuan preposisi (pernyataan sebagai teori) dengan menggunakan data sebagai evidensi.

Untuk memperoleh data yang berkaitan dengan konsep yang bersifat filosofis, keyakinan, kegiatan, serta artefact, peneliti menggunakan penggalian data dengan menggunakan pemilihan kriteria berdasarkan jaringan, yakni menetapkan informan penelitian berdasarkan informasi dari subjek lain sebelumnya. Seleksi ini digunakan sebagai dasar menentukan informan yang memiliki kekhususan ciri tertentu. Dalam aplikasinya, peneliti mengidentifikasi subjek penelitian yang memiliki kekhususan ciri, misalnya seseorang yang memiliki pengalaman dalam dialog yang terkait dengan masalah pemenitian.

Setelah wawancara, observasi dan analisis dokumentasi yang merupakan cara pengumpulan data, selanjutnya data dicatat secara deskriptif dan reflektif yang selanjutnya dianalisis. Analisis data ini dilakukan dalam rangka mencari dan menata (mengkonstruk) secara sistematis catatan (deskripsi) hasil 
wawancara, observasi, dan lainnya untuk meningkatkan pemahaman dan pemaknaan peneliti tentang obyek penelitian. Penelitian ini menggunakan perpaduan dua metode analisis data yakni: Pertama, interaksi ide. Metode ini digunakan untuk mengembangkan teori. Pola pikir ini berangkat dari empiri dengan mendialogkan antara teori dan data lapangan dan selanjutnya yang bukti empiri ini digunakan untuk menyusun abstraksi. Metode ini menggunakan pola pikir historik-ideograpik, yakni tata pikir yang mengatakan bahwa tidak ada kesamaan antara sesuatu dengan yang lain karena beda waktu dan konteks. Kedua, Comparative constant dilakukan oleh peneliti dengan proses mencari konteks lain dalam rangka mencari "makna" di balik yang empiri sebagaimana di maksud di atas, hingga peneliti memandang cukup bagi konseptualisasi teori. Pada tahap ini tata/pola pikir analisis data yang dipakai adalah pola pikir reflektif, yakni proses "mondar-mandir antara yang empirik dengan yang abstrak (makna). Satu "kasus empiri" dapat menstimulasi berkembangnya konsep abstrak yang luas dan menjadikan mampu melihat relevansi antara empiri satu dengan empiri lain yang termuat dalam konsep abstrak baru yang dibangun oleh peneliti.

\section{Hasil dan Pembahasan}

\section{Materi Ujian dan Penguji BTA-PPI}

Rancang bangun keilmuan yang ada di IAIN Purwokerto dituangkan dalam kurikulum dan berorientasi pada penguasaan materi (maddah) yang berporos pada cabang keilmuan yang sudah mapan seperti Tafsir al-Qur'an wa ulumuhu, al-Hadits wa ulumuhu, al-Fiqh wa ushuluhu, ilmu Tasaawuf dan ilmu Kalam. Pendekatan pembelajaran Agama Islam dalam beberapa sisi mengedepankan aspek hafalan dan analisis-kritis dalam praktik pengalaman ibadah. Dalam situasi seperti inilah, transformasi nilai-nilai etika ilahiyah melalui lembaga pendidikan memegang peranan yang signifikan dalam ikut meluruskan penyimpangan-penyimpangan akibat ekses negatif IPTEK. Orientasi dasar dari pendidikan yang berbasis agama adalah upaya memanusiakan manusia dengan menekankan harmonisasi hubungan, baik dengan sesama manusia maupun dengan lingkungan alamnya, yang ditopang dengan nilai-nilai ilahiyah.

Materi kegiatan meliputi baca tulis al-Qur'an (Tartil dan Tajwid, Hafalan Juz Amma, dan Imla), serta pengetahuan pengamalan ibadah (thaharah, shalat, puasa, zakat dan haji). Pada praktiknya, setiap peserta diuji oleh dosen penguji yang telah lulus ujian BTA/PPI. Pengambilan keputusan kelulusan dilakukan oleh tim penguji dari Ma'had. Jika ujian materi tartil/tajwid dinyatakan tidak lulus, maka ujian untuk materi lainnya tidak 
dilanjutkan dan yang bersangkutan dinyatakan tidak lulus. Hasil ujian dinyatakan lulus, jika ada satu komponen ujian dinyatakan lulus. Bagi peserta yang dinyatakan tidak lulus, diharuskan untuk belajar di pondok pesantren selama satu tahun atau sampai bisa dinyatakan lulus.

Dari materi itulah terlihat IAIN Purwokerto berusaha menjadi sebuah institusi yang baik. Hal itu dapat dilihat dari proyeksi pandangan dan arah capaian, baik secara konseptual maupun aplikatif. Proyeksi pandang dari sebuah institusi akan menjadi identitas dan konstruksi sistem nilai yang selalu diwujudkan dalam kehidupan. Hal itu tentunya dibuat dan dibentuk dengan mengacu pada realitas yang ada sehingga ada kontekstualisasi yang jelas. Oleh karena itulah, dengan melihat keadaan dari IAIN Purwokerto yang memiliki ekspektasi tinggi dalam ranah akademik dan ekspektasi sosial sebagai bentuk pengabdian, maka diharapkan agar IAIN Purwokerto dapat memainkan perannya dalam mengembangkan berbagai ilmu pengetahuan keagamaan.

Dalam hal ini, penguji adalah dosen yang ditetapkan dengan SK Rektor. Penetapan kriteria dosen penguji kompetensi Dasar BTA dan PPI di Institut Agama Islam Negeri Purwokerto kriterianya adalah: Pertama, dosen dengan jabatan akademik Guru Besar atau Lektor Kepala yang berlatar belakang pendidikan PTKI/Pondok Pesatren, ditetapkan sebagai penguji BTA dan PPI. Kedua, dosen dengan jabatan akademik Guru Besar atau Lektor Kepala yang berlatar belakang pendidikan non PTKI/non Pesantren, diberi pilihan boleh tidak menjadi penguji atau jika menghendaki menjadi penguji harus melalui seleksi penguji BTA dan PPI; Ketiga, dosen dengan jabatan akademik lektor yang berlatar belakang pendidikan PTKI/Pondok Pesantren, ditetapkan sebagai penguji BTA dan PPI; Keempat, dosen dengan jabatan akademik lektor yang berlatar belakang pendidikan non PTKI/Pondok Pesantren, harus mengikuti seleksi penguji BTA dan PPI; Kelima; dosen dengan jabatan akademik Asisten Ahli, tanpa memandang latar belakang pendidikanya, harus mengikuti seleksi penguji BTA dan PPI; Keenam, dosen tetap non PNS atau dosen luar biasa yang dinyatakan lulus setelah mengikuti ujian seleksi penguji BTA dan PPI; dan Ketujuh, penguji dosen penguji BTA dan PPI adalah Pimpinan IAIN (Rektor, Wakil Rektor I, II, III), Dekan yang berlatar belakang pendidikan PTKI/Pesantren, Ketua dan Sekertaris Lembaga Penjaminan Mutu, dan Mudirul Ma'had.

\section{Pesantrenisasi bagi Mahasiswa: Pembentuk Spiritualitas}

IAIN Purwokerto memiliki tujuan yang baik, yakni dengan berusaha untuk menyiapkan mahasiswa agar menjadi anggota masyarakat yang memiliki kemampuan akademik dan/atau profesional, yang dapat menerapkan, mengembangkan dan menciptakan ilmu pengetahuan berdasarkan azas Islami. 
Menurut Drs. H. Munjin, M.Pd.I., selaku Wakil Rektor I (2015), mahasiswa IAIN Purwokerto diharapkan menjadi intelektual muslim yang memiliki kompetensi dasar dalam bidang agama dan pengamalan peribadatannya tidak perlu diragukan. Hal ini sejalan dengan visi dan misi IAIN Purwokerto terkait dengan gagasan ideal bagi setiap mahasisa untuk memiliki kompetensi sebagai smart and good citizen, agamawan, ilmuwan dan budayawan.

Perguruan Tinggi mempunyai posisi strategis yang dalam konteks civilisasi. Hal ini berfungsi memediasi proses komunikasi kelas atas dengan kelas bawah melalui relasi ilmu pengetahuan. Terkait mandat Perguruan Tinggi sebagai lembaga pendidikan, proses mediasi yag bersifat kompleks dan tidak bisa dilakukan sendiri. Mediasi yang secara langsung bisa dilakukan Perguruan Tinggi adalah mediasi yang bersifat edukatif. Namun demikian, Perguruan Tinggi bisa memobilisasi institusi-institusi lain yang memiliki mandat berbeda untuk secara kolaboratif memediasi proses civilisasi masyarakat. Oleh karena itu, dalam membentuk mahasiswa menjadi intelektual yang berakhlakul karimah, proses pembentuk karakter dilakukan dalam bentuk pengamalan secara langsung. Pendidikan bukan hanya sebatas transformasi ilmu pengetahuan, tetapi juga pembentukan jati diri pada seseorang untuk memiliki pandangan baru berdasarkan sistem nilai sebagai karakter.

Menurut Dr. H. Suwito NS, M.Ag., (2015), IAIN Purwokerto sebagai institusi pendidikan berlabel Islam, maka punya tanggungjawab akademis terhadap setiap mahasiswanya agar dapat memiliki kemampuan dasar bidang agama Islam. Tujuannya, agar mereka dapat menjalani proses pendidikan secara baik, yang pada muaranya mampu menjadi seorang intelektual dengan wawasan keagamaan yang baik bagi masyarakat. Rencana pengembangan akademik pun berlandaskan pada visi dan misi IAIN Purwokerto yang meliputi bidang-bidang pendidikan-pengajaran, penelitian dan pengabdian kepada masyarakat yang memiliki relevansi dengan kebutuhan steakholder. Dalam posisi inilah, pendidikan menjadi interaksi komunikatif dalam membentuk prilaku melalui pengamalan ritus keagamaan. Pengamalan keagamaan membutuhkan ruang dan waktu tersendiri untuk menjadi sebuah kebiasaan dan akhirnya menjadi pola dalam kehidupan sehari-hari. Hal inilah yang dilakukan oleh IAIN Purwokerto dalam rangka membentuk prilaku mahasiswa berakhlakul karimah untuk mengondisikan mahasiswa berada dalam lingkaran pengamalan keagamaan di pondok pesantren.

IAIN Purwokerto dalam proses mewajibkan BTA/PPI menjalin kerjasama dengan 22 pondok pesantren, yakni Al-Amin Pabuaran, Al-Amin Mersi, Al-Falah /Qiraati, Al-Hidayah, Al-Husaini, Al-Ikhsan, Al-Ittihad, AnNajah, Ath-Thohiriyah, Bani Rosul, Darul Abror, Darus Salam, Fathul Huda, Fatkhul Mu'in, Nurul Iman, Nurus Syifa, Roudlotul Ulum, Darul Falah, 
Zam-Zam, El-Fira, Roudlotul Qur'an II, dan Sirojudin. Beberapa pondok pesantren tersebut ada yang merupakan milik dosen IAIN Purwokerto atau ada juga dosen yang turut serta menjadi pengelola/ustadz di pondok. Dalam proses kerja sama ini, setiap tahun senantiasa ada evaluasi yang dilakukan oleh IAIN dengan pesantren mitra untuk mengalisis permasalahan-permasalahan yang dihadapi. Bahkan, ada modul yang digunakan sebagai kesamaan persepsi pembelajaran BTA/PPI di pondok pesantren, sedang materi yang lain dapat dikembangkan oleh pondok itu sendiri sesuai dengan program masing-masing. Oleh karena itu, ada sinkronisasi pandangan keilmuan di perguruan tinggi agama Islam dengan materi yang ada di pondok pesantren.

Pesantren dipilih karena berisikan banyak pengetahuan dan praktik pengamalan ibadah secara langsung dalam jangka waktu tertentu. Orang sering salah dengan arti kata 'pengetahuan' yang harus dikaitkan dengan pemikiran dan perenungan yang ketat sampai membuat dahi berkerut. Pengetahuan di pondok pesantren berbeda dengan filsafat yang menohok anjuran secara langsung, juga berbeda dengan ilmu sosial yang lebih menampilkan kebudayaan dan masyarakat dalam kelompok secara umum. Sistem pembelajaran di pondok pesantren menampilkan dimensi kemanusiaan secara kahrismatis (melalui tokoh kiai) dengan struktur religius yang melingkupinya. Nilai-nilai Islami masuk ke dalam jiwa, rasa, dan kalbu, untuk menjadikan kenyataan santri (yang merupakan mahasiswa) sebagai bagian dari praktik ibadah. Santri dibawa kepada alam spiritual untuk merasakan dan mengalami kehidupan pesantren yang penuh dengan nilai-nilai yang berakar pada alQur'an dan Hadis.

Proses pembelajaran di pondok pesantren dilakukan dengan interaksi secara langsung melalui tata kehidupan yang berpegang pada al-Qur'an dan Hadis dapat menjadi budaya tersendiri yang kokoh. Bahkan, di pondok pesantren juga diajarkan Kitab Ta'lim Muta'alim terkait dengan hakikat belajar, juga pengamalan ilmu dan cara penyebarannya. Hal ini dapat membentuk praktik pengamalan ibadah sebagai keseharian yang dilakukan secara terus-menerus dalam sebuah kebiasaan di pondok pesantren.

Dengan adanya kebiasaan hidup dan tinggal di pondok pesantren, maka menjadikan mahasiswa terpengaruh budaya hedonis rendah. Tidak adanya kesempatan untuk mengakses ruang-ruang glamor seperti diskotik atau tempat karaoke, berada dalam trend-mode, dan persaingan gengsi, maka membuat pikiran lebih lurus berkonsentrasi dalam belajar. Lingkungan pondok pesantren yang mewajibkan santri mengaji dari mulai ba'da asar hingga jam 10 malam, juga subuh hingga pagi terang tanah menjadikan kehidupan lebih terisi materi kegamaan secara disiplin.

Kurikulum pondok pesantren yang telah menjadi mitra IAIN 
Purwokerto dilakukan dengan standarisasi pembelajaran yang dirancang sesuai dengan keberadaan mahasiswa dalam pengembangan materi BTA-PPI. Memang konsep dan metode pembelajaran diserahkan kepada masing-masing dari pondok pesantren. IAIN Purwokerto hanya membuat kriteria dan melalukan evaluasi setiap tahun sekali. Materi pokok seperti tartil dan tajwid, hafalan juz amma, dan imla wajib ada, dan lebih diutamakan untuk santri yang memang belum pernah mondok sama sekali. Materi ini memang merupakan materi dasar di sebuah pondok pesantren, sebelum mereka belajar kitab-kitab tafsir ataupun kitab lainnya. Oleh karena itu, bagi pondok pesantren yang diajak kerjasama oleh IAIN Purwokerto merasa tidak ada keberatan sama sekali. Malahan, ada semacam motivasi tersendiri dari pondok pesantren untuk melakukan pembelajaran dengan baik dengan menunjukkan kualitas yang terlihat oleh masyarakat secara umum. Boleh dikatakan, saat ujian BTA-PPI akan menjadi pertaruhan reputasi pondok pesantren terkait dengan kelulusannya.

Dari sistem pembelajaran tersebut diharapkan akan menghasilkan lulusan yang kompetitif dalam kehidupan bermasyarakat, berbangsa, dan bernegara. Pembelajaran di pesantren dilakukan dalam wujud pengembangan materi BTA-PPI. Hal ini berdasar pada hakikat pembinaan mahasiswa IAIN Purwokerto, yakni sebagai usaha yang dilakukan secara sistematis bagi penciptaan iklim dan kondisi yang memberikan kemungkinan bagi pengembangan diri dalam membentuk karakter sejalan dengan tujuan Sistem Pendidikan Nasional.

Pengetahuan tidak hanya dilakukan dalam proses pembelajaran tatap muka secara langsung, melainkan juga dapat dilakukan dengan proses internalisasi nilai kehidupan sehari-hari. Pembelajaran secara langsung menjadikan santri memiliki akhlak mulai sesuai dengan akhlak kiainya. Dengan adanya filosofi ngalap berkah dalam pencarian keilmuan (menghilangkan kebodohan) yang didoakan oleh kiai agar mendapat ridha dari Allah SWT sehingga dapat menjadi ilmu yang bermanfaat. Dalam hal inilah, berlaku adanya anugrah (petunjuk) dari Allah SWT bagi ilmu yang bermanfaat.

Pengetahuan itu sendiri berbentuk seperti jaring laba-laba. Oleh karena itu, pembelajaran di pondok pesantren selalu terhubung dengan kehidupan, bahkan terhubung dengan makrokosmos yang hidup karena manusia berada di lingkaran semesta: arena kehidupan yang menjadi wujud. Dunia ini terbentuk dalam jaringan pengetahuan yang saling terhubung, begitu pun sistem di pondok pesantren sebagai salah satu elemen pengetahuan yang menghubungkan nilai religius dengan praktik kehidupan sehari-hari. Dunia pesantren terhubung dengan kehidupan dalam "keberadaan antara", yakni 
antara Ilahi dan manusiawi yang membentuk dialektika. Dialektika itu membentuk hierarki melalui sistem spiritual yang menampilkan pengetahuan bagi santri di pondok pesantren.

Pandangan ibadah tidak hanya mengacu pada ritual untuk berdialog langsung dengan Tuhan, melainkan juga dapat dilakukan dengan turut berpartisipasi menjaga keindahan lingkungan karena "sesungguhnya Tuhan juga mencintai keindahan". Orang-orang yang memahami hakikat semacam ini lebih banyak ditemukan di pondok pesantren yang memiliki kedalaman nilai dan rasa untuk mengenali dirinya sendiri dan mentransformasikan dalam hidup. Dalam dialektika lingkungan yang harmonis memang sudah seharusnya manusia memahami bahwa keindahan inderawi pun dapat menuju pada hakikat keindahan tunggal sang Pencipta.

Pembinaan BTA/PPI bagi mahasiswa IAIN Ppurwokerto itu sendiri merupakan upaya yang terus-menerus dilakukan yang didasarkan pada pencapaian kompetensi mahasiswa itu sendiri. Adapun tujuan utamanya adalah mengantarkan seluruh mahasiswa IAIN Purwokerto mencapai tingkat kesarjanaan dan sekaligus mematangkan keperibadiannya sesuai dengan potensi yang dimiliki masing-masing mahasiswa dengan nilai agama. Dengan demikian, kondisi tersebut akan melahirkan civitas akademik muslim yang sesuai dengan cita-cita pendidikan IAIN Purwokerto yang Islami. Adanya pesantren akan membentuk akademisi muslim yang berakhlak mulia, cakap, percaya diri sendiri dan berguna bagi masyarakat dan agama. Ada suasana kehidupan kemahasiswaan yang harmonis dan kondusif bagi pengembangan nilai keilmuan dan Keislaman

Dunia pesantren dengan pengetahuan yang halus berbisik pelan melalui cela-celah perasaan untuk membentuk spiritualitas seseorang. Adanya trasformasi ilmu pengetahuan karakter di pesantren inilah yang mendorong orang untuk mengetahui dengan pelan dan cermat akhlak mulia. Selangkah demi selangkah, budaya pesantren menggerakan hati santri tanpa paksaan dan tanpa tekanan. Spiritualitas selalu berurusan dengan rasa yang hadir melalui penghayatan, maupun penginsanan diri. Pada wilayah itu, setiap orang bisa masuk untuk menikmati spiritualitas, dan pada saat yang sama akan hadir "iman" berdasarkan keyakinan. Dalam hubungan pendek yang dijalin oleh rasa, ada pengetahuan yang masuk dan diterima sebagai wawasan baru bagi santri.

Dalam arus modernisasi ini, banyak orang yang berada dalam pengaruh fantasi dan hasrat. Santri di zaman seperti sekarang ini harus menjadi orang yang peka dan peduli pada lokalitas agar nilai-nilai dapat ditransformasikan dengan baik. Ia membaca bahwa kapitalisme tidak hanya berada di dalam tatanan pemerintahan, tetapi juga sudah mulai masuk di lingkup pondok 
pesantren. Oleh karena itu, nilai dan kekayaan luhur sebagai bentuk "kesadaran praktis" harus dipahami dengan baik.

Melalui pendalaman nilai-nilai Islami di pesantren, diharapkan ada kesadaran dari santri untuk dapat keluar dari lingkaran kebodohan dan kekolotan. Pengetahuan di dalam pembelajaran di pesantren bergerak melalui kesadaran yang terjalin dalam ketaksadaran. Pondok pesantren-dengan kekuatan doa-doa-mampu membentuk dunia yang terus hidup di dalam spiritualitas seseorang. Belum lagi, pengetahuan pada kitab-kitab tradisonal yang penuh dengan pesan moral telah mencerahkan santri untuk mendapatkan pemahaman Yang Hakiki. Boleh dikatakan, ketika krisis moral melanda Indonesia belakangan ini, maka pondok pesantren hadir menjawab kegelisahan zaman untuk mulai kembali pada spiritualitas. Pondok pesantren menjadi pintu dengan adanya pengetahuan yang disampaikan melalui sebuah "pengalaman-berkah" sehingga santri menerima dengan senang. Dari pemahaman dan pendalaman pengetahuan di pesantren inilah, seseorang bisa dirahkan untuk lebih mencintai tanah air Indonesia. Hal ini karena Islam mengajarkan agar manusia tidak hanya beribadah saja, melainkan juga menjadi bagian dari integritas masyarakat, bangsa dan negara.

Dari keadaan itulah, diraih hasil bahwa mahasiswa IAIN Purwokerto memiliki pemahaman yang utuh tentang pokok-pokok ajaran agama Islam, dengan indikator: Memiliki pengetahuan tentang relasi Tuhan, manusia dan alam; Memiliki pengetahuan tentang konsep iman, Islam dan ihsan; dan Memiliki pengetahuan tentang sumber-sumber ajaran Islam. Pada sisi lain, mahasiswa memiliki kemampuan mengamalkan ajaran agama Islam, melalui pengetahuan tentang makna dan tata cara peribadatan dan kemampuan mengamalkan peribadatan. Oleh karena itu, pada praktiknya, mahasiswa yang dianggap lulus memiliki penghayatan mendalam tentang makna ajaran Islam, memiliki komitmen dalam mengamalkan ajaran agama Islam, memiliki konsistensi dalam mengamalkan ajaran agama Islam, dan memiliki kemampuan transformatif nilai-nilai ajaran Islam.

\section{Kesimpulan}

Setelah mendalami dunia pesantren untuk mendapat Pembinaan BTAPPI, mahasiswa mengembangkan kompetensi dasar BTA \& PPI sebagai bekal untuk kembali menjadi bagian dari masyarakat. Mahasiswa yang juga merupakan santri menemukan pengetahuan, menemukan kembali moralitas dan nilai, juga menjadikan pandangan lebih kompleks. Dunia pesantren selalu berusaha mengajak orang untuk peka terhadap realitas dengan mendasarkan pandangan pada al-Qur'an dan Hadis. Mahasiswa yang lulus dari IAIN 
Purwokerto tidak hanya memberikan pantulan keilmuan secara permukaan saja, tetapi pengamalan kehidupan yang sangat berharga melalui interaksi religius di dunia pesantren. Pembinaan BTA-PPI bagi mahasiswa IAIN Purwokerto ini terlaksana dengan baik karena mahasiswa mamapu mengetahui tartil dan tajwid yang benar untuk bisa diimplementasikan ke dalam kehidupan sehari-hari. Mereka juga mengetahui pola imla dan materi pentingnya hafalan surat pendek. Adapun terkait dengan pengetahuan pengamalan ibadah, mereka dapat meningkatkan kemampuan dasar sebagai penguasaan dasar dalam kehidupan bermasyarakat, berbangsa, dan bernegara.

\section{DAFTAR PUSTAKA}

Ahmadi, Abu dan Widodo Supriyono. 2004. Psikologi Belajar (edisi revisi). Jakarta: Rineka Cipta.

Bertenz, K. 2006. Psikoanalisis Sigmund Freud. Jakarta: Gramedia Pustaka Utama.

Ebrahim Azarpour, dkk, "Study Medicinal Plants In Holy Quran" in International Journal of Plant, Animal and Environmental Sciences Vol. 4, Issue 2, April Juni 2014.

Freire, Paulo. 2007. Politik Pendidikan: Kebudayaan, Kekuasaan, dan Pembebasan.. Yogyakarta: Pustaka Pelajar.

Freud, Sigmund. 2006. Pengantar Umum Psikoanalisis. Yogyakarta: Pustaka Pelajar.

Muchtar, Naqiah. 2012. Ulumul Qur'an. Purwokerto: STAIN Press.

Murata, Sachiko dan William C. Chittick. 2005. The Vision of Islam. Yogyakarta: Suluh Press.

Mohd Aderi Che Noh, Amjad Hussein, Othman Ghani and Asmawati Suhid, "The Study of Quranic Teaching and Learning: A Review in Malaysia and United Kingdom" Middle-East Journal of Scientific Research 15 (10): 1338-1344, 2013

Muhadjir, Noeng. 1996. Metode Penelitian Kualtitatif. Yogyakarta: Rakesarasin.

Munjin. 2015. "Pidato Pembukaan Pembinaan BTA-PPI bagi Mahasiswa IAIN Purwokerto di Tahun 2015”. Purwokerto: IAIN Purwokerto.

Suwito. 2015. "Sambutan dalam Pembukaan Pembinaan BTA-PPI bagi Mahasiswa IAIN Purwokerto di Tahun 2015”. Purwokerto: IAIN Purwokerto. 
